\title{
Youth voices in post-English riots Tottenham: the role of reflexivity in negotiating negative representations
}

\author{
by Dr Julius Elster
}

\section{Abstract}

Numerous negative representations of youth emerged in the aftermath of the 2011 English riots. This paper intends to fill a gap in the literature on the 'riot-affected' areas by looking at how youths from Tottenham (the North London constituency where a peaceful demonstration escalated into the English riots of 2011) deal with stereotypical and homogeneous portrayals put forward by the British mainstream news media and many Government Ministers. In drawing on an alternative conceptualisation of reflexivity that spells out how reflexive orientations relate to lived experiences, the paper aims to open up novel pathways for understanding youth reflexivity in the context of being regularly subjected to negative representations. This is achieved by tying reflexive activity more closely to Alfred Schütz's notion of 'stock of knowledge.' The study applies qualitative methods to empirically address how a group of eighteen 15- to 25-year-olds from Tottenham reflexively negotiate the harmful consequences of stigmatised identities. The most striking conclusion to emerge from the data is that Tottenham's young people embody a diverse range of youth identities and reflexive attitudes; a conclusion that flies in the face of the way in which much of the media depicted youths after the riots. 


\section{Keywords}

2011 English riots, moral panic, reflexivity, representations of youth, sociology of youth, stereotypes, stock of knowledge, youth studies, youth voices

\section{Introduction}

This paper began as a response to concerns expressed by numerous youths in the aftermath of the English riots of 2011. Drawing from personal experience of working with youths from the 'riotaffected' areas, I encountered many young individuals speaking of how they are misrepresented and perceived in negative ways by the media and people outside their 'ingroup.' The exclusion of youth voices from the 'dominant discourse' that emerged after the riots gave rise to representations that characterise youths from the respective areas in stereotypical and homogeneous terms. In particular, the North London area of Tottenham, where the riots erupted as a result of the deep sense of injustice at the police killing of a young, unarmed Black Tottenham man, has been at the receiving end of negative stereotypes. Since 2011, youths from Tottenham have been labelled 'feral rats' (Clarke, 2012: 297), and portrayed as 'passive participants' (Dillon and Fanning, 2019: 611) and 'delinquents' (Boyce Davies, 2013: 181) by the British news media and politicians. It is youths from this area that are the core of the present paper. The qualitative data is based on in-depth interviews with eighteen 15 - to 25 -year-olds, and my aim is to explore how young people in Tottenham:

(a) negotiate stigmatised youth identities;

(b) employ reflexivity and draw on lived experiences as they navigate through complex and challenging circumstances.

In contrast to most literature on Tottenham since the English riots, the below intends to demonstrate the importance of recognising reflexivity to uncover heterogeneity in youth and the ways in which young people deal with the oppressive effects of stereotyping and negative representations. Reflexivity is a widely discussed concept and a contentious issue in the field of youth studies (e.g., Farrugia, 2013; 2018; Farrugia and Woodman, 2015; Threadgold, 2018) and 
sociology more broadly (e.g., Adams, 2006; Nico and Caetano, 2017; Sweetman, 2003). While I follow Margaret Archer (e.g., 2012: 1) in defining reflexivity as the ability to reflect upon ourselves while taking into account our social circumstances, I, like many other youth researchers, do not agree with her insistence on a separation between agentic capacities, such as reflexivity, and the social domain. To demonstrate that reflexive activity can be continuous with 'social embeddedness,' reflexivity will be considered in relation to Alfred Schütz's 'stock of knowledge.' The latter notion denotes a 'stock' of previous lived experiences that have accumulated over time through simply engaging in the social world. Construing youth reflexivity as a capacity that must to some degree draw on a stock of knowledge allows us to map out how life biographies affect young people's reflexive negotiation in a world saturated with stereotypical representations of youth. Before considering the concept of reflexivity in more detail, I shall provide a brief indication of how this paper is situated within the existing literature on stigmatising media representations of youth.

The final sections of this article discuss the research findings. Here, the research participants - all from Tottenham - state emphatically that, since the 'English riots,' the media and people from outside the area of Tottenham:

1. tend to misrepresent them;

2. have no real sense of 'what [they're] going through' (to quote one of the participants); and,

3. portray them as a homogeneous entity.

The fact that Tottenham's 40,000 under-25s epitomise a 'super-diverse' community representing a complex blend of heterogeneous social relations and perspectives on life - was factored out of the 'dominant discourse.' To shed light on this omission, I centre and explore the reflexive activity and subjective accounts of those who bore the brunt of the media onslaught that followed the 2011 riots. In contrast to some interpretations of youth reflexivity (e.g., Nico and Caetano, 2017), the findings show no sign of any correlation between the socioeconomic condition of Tottenham's youths and reflexivity being in short supply. In fact, life in Tottenham appears to consist of youths who regularly measure their own situations up against their social context, which is the hallmark of reflexive activity, despite facing the imposition of negative stereotypes on an everyday basis. 


\section{Tottenham and its youths in context ${ }^{1}$}

Tottenham's ethnic, religious and cultural diversity makes it one of the most diverse constituencies in the world (Visser, in press). While 'white British' people make up about 80\% of England's population, the proportion is $22.4 \%$ for Tottenham (Nomis, 2019). With more than 200 first languages spoken (Independent Panel on Tottenham, 2012: 34), few places in the world can boast of a more diverse cultural environment than this corner of North London. Tottenham is, thus, emblematic of London's ethnic and cultural diversity, and a paradigm example of so-called 'super-diversity,' a term coined by Vertovec (2007: 1024) to 'underline a level and kind of complexity surpassing anything [...] previously experienced.' In spite of this, as I shall soon turn to, the discourse surrounding Tottenham paints a homogeneous picture of its youth population, often accompanied by stereotypical representations.

While local youths perceive diversity as being a positive attribute of their neighbourhoods (Visser, in press; Wessendorf, 2014: 119), Tottenham is associated with a range of socioeconomic issues. With few amenities for young people (Jefferson, 2015: 12) and 42.6\% of children living in poverty (End Child Poverty, 2018), Tottenham is ranked as having some of the highest level of youth poverty across the UK. Unemployment rates in Tottenham are also higher than the London average. One Tottenham ward, Northumberland Park, where many of my study's research participants stem from, had the highest out-of-work benefit claim rate in London, at 31.5\%, in the months after the 2011 riots (Independent Panel on Tottenham, 2012: 45). Tottenham's unemployment often coexists with the increasingly precarious position of young adults in the labour market and in their pathways into adult life. Underlying these socioeconomic issues, as Stott et al. (2017: 969) call attention to, are public sector cuts designed as a response to the 'economic crash' that plunged the UK into recession in 2008. Public services bore the brunt of the 'spending squeeze,' legislated in line with the Conservative government's austerity programme, and youth provisions in Tottenham became almost nonexistent as a result

\footnotetext{
${ }^{1}$ Where appropriate, I favour the plural form 'youths' to avoid conceptualising the youth demographic in monolithic terms. Despite being pregnant with negative connotations in certain contexts, I, like many other youth researchers, believe the term 'youth,' per se, should not be a determinant as to whether those identified as such have certain qualities - negative or otherwise.
} 
of the drastic cuts to services for young people. The under-funding of youth services was accompanied by the change in how youth and outreach programmes were developed and evaluated - from a focus on informal and youth-centred approaches to short-term provisions with a focus on more measurable outcomes (de St Croix, 2018: 415, passim). The result was an environment shaped by austerity measures that treated youths as a static category - a homogeneous group - and led to few job opportunities beyond precarious contracts and unreasonably low wages.

These structural impediments, however, do not define Tottenham's youths or prescribe how they go about their lives, as we shall see. Despite some young people's constrained and precarious circumstances, pathways to adulthood may still encompass heterogeneous life trajectories and identity-forming processes where reflexive orientations are regularly employed (cf. Butcher, 2019). At any rate, many social and political commentators link these circumstances, including the disproportionate impact of stop-and-search on Black people in Tottenham, ${ }^{2}$ to the disturbances that escalated into the riots that swept through England in August 2011.

\section{Misrepresentations and the English riots of 2011}

The English riots gave rise to a large body of literature, and are still attracting attention from the British news media, the House of Commons and the public at large. A significant prelude to the initial unrest was the long-standing hostile relationship between youths and local police in Tottenham and the fatal shooting of Mark Duggan, a 29-year-old Black male from Tottenham's Broadwater Farm estate. A crowd made up of Mr Duggan's family, local youths and community leaders gathered outside Tottenham police station on 6 August 2011, protesting the failure of the police to provide family members with a formal notice of the killing. What started as a peaceful protest escalated when no high-ranking officer was willing to address the questions raised by the

\footnotetext{
${ }^{2}$ In a single month (June 2011, two months before the riots), the Metropolitan Police Service conducted '1,614 stopand-searches in Haringey [the borough in which Tottenham is situated], of these 91.4\% did not lead to any arrest. Such activities were likely to have been highly racialized' (Stott et al., 2017: 969).
} 
protesters. The following four days and nights, around 15,000 individuals across several English cities took to the streets; five people lost their lives and hundreds were injured.

Not long after the initial outbreak, politicians (as expected) provided decisive diagnoses of the root causes. Too many political commentators reduced the action of those involved in the riots to violent consumerism. According to Newburn et al. (2015: 987), 'the danger in so doing is that the "political" and protest elements of the riots become marginalized.' A stereotypical picture of those associated with the riots was painted by the government as many ministers referred to the youths from the 'riot-hit' areas as 'thugs' and members of a 'feral criminal underclass' (Home Affairs Committee, 2011: 5; cf. Clarke, 2012: 297; Jefferson, 2015: 20; Tyler, 2013b: $\S 3.1,4.2$ ). In an area of about 40,000 people under the age of 25 , only nineteen Tottenham teenagers were arrested in the wake of the riots. Yet, broad brush strokes were applied to portray all of Tottenham's young people with the same negative representations, reducing them to a single social category. As a result, the stigma that followed the emergence of the "riot discourse' is shared, to various degrees, by all youngsters growing up in Tottenham. To draw a picture solely based on those five days in August 2011 is 'both misleading and disingenuous to those communities that [experienced] harsh austerity cuts, the de-stabilisation of their local communities, and a shift in policy focus from welfare to the criminalisation of the poorest members of our society’ (McKenzie, 2013: §1.1).

Not all the literature on the neighbourhoods associated with the riots involved condemnatory portrayals of youths as irresponsible and vile, blaming them for whatever constraints they may face on their journey to adulthood. Some adopted more empathetic attitudes, emphasising macro factors such as structural inequality, institutional racism and socioeconomic underdevelopment as root causes of the distress and setbacks that youths may experience across their life course. This more 'empathetic' set of perspectives - typified by the many responses from sociologists (e.g., ibid.; Murji, 2018; Tyler, 2013a) - maintains that the underlying causes of the riots arose from regressive socioeconomic transformations in Britain (Newburn et al., 2018: 340). This set often acted as a critique of, and a counterbalance to, the 'condemnatory' one, which mainly emanated from the media and politicians. But the discourse that dominates the public perception of Tottenham's youths, according to the present study's interviewees, is the one that emphasises homogeneity across young people - as if they have the same 'negative cultural 
traits' - and fails to appreciate the variability in life course patterns that arise out of heterogeneous social relations and reflexive capacities. The report It Took Another Riot (Independent Panel on Tottenham, 2012: 72), produced on behalf of the Mayor of London, Boris Johnson, epitomises this discourse. The report reinforces the assumption that Tottenham is deprived of active youth subjectivities as it speaks specifically of Tottenham's residents as:

passive participants trapped in a vicious cycle of deprivation and degradation where unemployment, addictions, low educational attainment, poor health, youth alienation and crime inter-connect in a causal relationship as 'mutually reinforcing dynamics.' (Summarised by Dillon and Fanning, 2019: 611)

\section{Stigma, moral panics and 'them-and-us' attitudes}

UK's Prime Minister at the time of the English riots, David Cameron (2011), confined the behaviour of youths from areas such as Tottenham to 'criminality pure and simple' rooted in large-scale 'immorality' among the urban underclass. Threadgold's (2018: 10) reminder of how youths are typically treated in the public sphere comes to mind here: 'youth is evoked in all kinds of moral panics towards whatever current social problems need a scapegoat.' Events such as the English riots have given rise to a wealth of literature that draw on 'moral panic' frameworks. 'There is plenty of evidence,' Jefferson (2015: 20) says, to support the idea that the dominant constructions of the riots are best understood as a moral panic. To shape the 'riot discourse' and perceptual realties, Tyler (2013a: 149, 195) adds, mediating agencies operated to orchestrate public opinion by transforming the disturbances into a moral panic.

Stan Cohen's Folk Devils and Moral Panics ([1972] 2011) and Stuart Hall et al.'s Policing the Crisis ([1978] 2013) remain landmarks in the moral panic literature. While the former investigates the demonisation of working-class youth culture, the latter examines "why and how the themes of race, crime and youth - condensed in the image of "mugging" - come to serve as the articulator of the crisis [that society was slipping into]' (ibid.: 2). The marginalised groups discussed in Cohen's and Hall's works were represented in the media, just like the young people associated with 'riot-affected' areas such as Tottenham, as morally deficient people who create problems for 'mainstream society.' One common thread running through these cases, I suggest, is 
best described as 'them-and-us' attitudes. Media representations establish a hard-and-fast division between 'us' - the 'law-abiding members' of society - and 'them' - youths from marginalised social groups (Gordon, 2018: 44). In the case of the 2011 riots, the stereotype that makes them 'them,' rather than 'us,' is the 'revolting figure of the profligate, criminalised welfare recipient,' as indicated by Tyler (2013b: §6.3). The purpose of this division was most likely to hammer into the public consciousness the idea that the problem lies with 'them,' not with 'us,' and, thus, to delegitimise claims that socioeconomic factors, such as racist stop-and-search practices, deprivation and governmental budget cuts, played a role in the riots.

The construction of 'them-and-us' attitudes goes hand in hand with stigmatising processes. Since Goffman's now-classic work Stigma: notes on the management of spoiled identity (1963), stigma has been a key concept in sociology. Even though Goffman's take on stigma (ibid.: 3) as a process by which the reaction of others reduces an attribute to a 'tainted discounted one' has been invaluable as a foundation for other stigma-focused research, he paid little attention to the way in which neoliberal governance rely on stigmatisation to justify its policies and ideology (Tyler, 2018). This omission has become conspicuous as a result of the emphasis Tyler (2013a; see also Threadgold, in press) and 'moral panic theorists' (e.g., Cohen, [1972] 2011; Gordon, 2018; Hall et al., [1978] 2013) place on identifying the link between stigma and neoliberal governance's behind-the-scenes pulling of strings. Alongside this focus, there has been a recent surge of research interest in practices of resistance, in which stigmatised individuals intervene in stigmatising processes, and different ways that these individuals think - reflexively or otherwise - about stigma and stereotypical representations (e.g., Butcher, 2019; Habib, 2019; Threadgold, 2018; Tyler, 2013a). In looking at youth subjectivity, with a vital emphasis on how young people reflexively negotiate stigmatising representations, it is within the latter field of research that the present paper is grounded.

\section{Tying youth reflexivity to social embeddedness}

One aspect missing from the large body of literature on youths from the 'riot-hit' areas since the 2011 disturbances in England is a focus on how youths themselves negotiate their social 
environment. Looking at the correlation between young people's life trajectories and certain socioeconomic circumstances is valuable, but sheds little light on how the different variables relate. In order to bring 'How?'-type questions to the fore - e.g., how young people think of themselves in relation to their social environment or how social conditions affect their life choices - an exploration into (social) psychological processes is required. Without taking youth subjectivities into account, we are also more likely to portray those under scrutiny in homogeneous ways or draw upon stereotypical assumptions that not only misrepresent the young people, but can also have long-lasting harmful effects. This is my rationale for focusing on young people's mental ability to recognise their situation, behaviour or identity in relation to their social conditions, also known as 'reflexivity.' This paper's point of departure draws on Margaret Archer's celebrated take on reflexivity, which she (e.g., 2012) defines as reflection upon yourself while taking your social circumstances into consideration. However, Archer's social ontology, wherein the concept of reflexivity plays a central role, contains some thorny issues, some of which have already been identified (see, e.g., Akram and Hogan, 2015; Elster, 2017; Farrugia and Woodman, 2015).

As I have already pointed out, the need to investigate subjective capacities and listen to youth voices is particularly pertinent with respect to Tottenham's youths after the 2011 riots. Archer's work on reflexivity has done a great deal to challenge theories that consider humans to be merely the product of social structural forces. It has also been valuable in giving voice to young people's reflexive capacities and concerns. Archer's conceptualisation of reflexive deliberations, however, seems to operate as a 'blank canvas' given her insistence on a separation between reflexivity and the social realm. Her (e.g., 2012: 73; 2013: 6) 'structure-agency dualism' does not allow for the socially embedded constitution of reflexivity since it admits little into the interiority of the (reflexive) subject beyond agentic capacities, as Farrugia and Woodman (2015: 636) observe. As exemplified in the sections discussing the empirical findings, reflexivity is not an 'isolated' matter. Rather, it has its own subjective history consisting of lived experiences that are very much embedded both socially and temporally. A theoretical framework that is capable of accounting for how youth reflexivity can be continuous with social embeddedness is thus called for. 
Recognising the changing dynamics of capitalist societies and the fragmentation of traditional structures, many youth sociologists have added the notion of reflexivity to their conceptual toolbox in order to better explain how young people increasingly have to negotiate youth identities and transitions into adulthood. One vital source of inspiration for this line of theorising is Beck's individualisation thesis ([1986] 1992). While Archer understands reflexivity to be a universal characteristic of agency, Beck sees it as the age in which we find ourselves (Akram and Hogan, 2015: 607). Numerous youth researchers (e.g., France, 2007; Woodman, 2009; Wyn and Woodman, 2007) accept the general thrust of Beck's claims that it is getting harder to predict what lives of young individuals might look like drawing on traditional structures. But, while the individualisation thesis is seen as useful in explaining why youths increasingly have to reflexively negotiate life trajectories and identities, youth researchers rarely consider reflexive activity to be the only driving force behind life choices and identity-forming processes. On the contrary. Many draw on Bourdieu's theory of 'habitus' (e.g., [1980] 1990; [1979] 2010) to argue for the mutual dependence of reflexivity and socially embedded dispositions (e.g., Akram and Hogan, 2015; Farrugia, 2013; 2018; Farrugia and Woodman, 2015; Nico and Caetano, 2017; Sweetman, 2003; Threadgold, 2018). Rather than standing outside of habitus, reflexivity operates in relation to it. This line of thought, nevertheless, might result in understanding youth reflexivity in terms of degrees, especially with respect to where young people are on the socioeconomic ladder. Nico and Caetano (2017: 678) claim that 'economically disadvantaged individuals' with 'lower educational levels' - words often employed to portray youths in Tottenham - 'have not found, in their social contexts, favourable conditions for the development of a more scholastic and ontological reflexivity.' As we shall see, any tendency indicating a shortage of reflexivity among socioeconomic disadvantaged youths did not emerge from the present paper's findings. The 'level' of reflexive capacity among my research participants appears to have little to do with their respective socioeconomic background.

While sociologists of youth tend to combine reflexivity with habitus, or pit the two against each other, the present study has benefitted from tying reflexive activity more closely to the concept 'stock of knowledge.' The latter is preferred since it is particularly flexible with respect to the complex and sometimes contradictory ways that heterogeneous groups of individuals Tottenham's youths are a case in point - make sense of their experiences and surroundings. The 
term stock of knowledge was coined by the leading exponent of phenomenological sociology, Alfred Schütz ([1945] 1962: 208; see also Elster, 2017: 282-5). The stock of knowledge is an ever-expanding subjective repertoire of experiences, meanings and dispositions. By simply living through a range of experiences and engaging in the social world, people add to their stocks of knowledge. The stock of knowledge is hence a socially and temporally constituted 'vehicle' that provides guidance for making interpretations within increasingly complex social spaces. But, how does reflexive activity relate to the stock of knowledge?

Early in the interview process, it was evident that the research participants' reflexive deliberations were not merely rooted in the 'here and now.' As Schütz ([1945] 1962: 208) points out, '[a]ll interpretation of this world is based upon a stock of previous experiences of it' and it seems plausible that reflexive thoughts would make use of the same 'stock.' If we were to accept this line of reasoning, then youths draw upon their stocks of knowledge as background configurations whenever they exercise their reflexive capacities. In tying the stock of knowledge to reflexivity, I believe we are in a better position, as we shall see in the latter sections of this paper, to do justice to the complexity and diversity of youth experiences.

\section{Research design}

As mentioned at the outset of this paper, my previous experience in managing community outreach programmes for youths in Tottenham and the surrounding area helped in forming my initial empirical problem. While there are epistemological challenges of knowing the research site, which led me to frequently reflect on the condition through which my research was produced, my positionality played for the most part a positive role in developing rapport with the interviewees and gaining rich data.

This paper draws on qualitative research conducted between September 2016 and June 2017. The fieldwork that forms the basis for my enquiry is made up of semi-structured interviews with eighteen 15- to 25-year-olds (eleven female/seven male) whose names have been pseudonymised. Research participants were drawn from four different organisations delivering youth outreach programmes in Tottenham and the majority of the interviews were conducted at 
Tottenham Hotspur stadium. ${ }^{3}$ By involving multiple youth organisations, some level of diversity was ensured. The study sample - all but one from different Black and minority ethnic backgrounds - reflects more or less the demographic profile of Tottenham's young people.

Due to the importance of 'follow-up interviews,' where the focus was on a more in-depth investigation into past experiences, the aim was to complete three face-to-face interviews with each participant. However, as a result of my over-rigorous approach to safeguarding, no contact details were exchanged, which, in turn, made it difficult to arrange future meetings between the interviewee and me. In most cases, nevertheless, two interviews or more were conducted with each interviewee. Although most interviews were carried out on a one-to-one basis, two interview sessions were with a quartet of young people (50/50 male/female ratio) while two female informants preferred one-to-two interviews. In order to enter into a meaningful dialogue, interviews lasted for at least 45 minutes each, but rarely more than an hour and a half. The interviews revolved around how the young person reflects on her or his multiple identities, as well as experiences of growing up in an oft-stigmatised neighbourhood.

After the interviews were verbatim transcribed in full, close readings of the data followed, placing codes - line-by-line commentary - in relevant passages. Before moving on to a more 'active' interpretation, the thematic analysis involved a descriptive assessment of the 98-page transcript, focusing on life trajectories and identity claims of the young people. The aim here was to develop a coding frame based on themes developed deductively (e.g., 'reflexivity' and 'youth identities'), through previous empirical research and from inductive analysis of the raw data. An example of the latter is the notion 'stock of knowledge,' which was introduced after the fieldwork as it became clear that I needed to conceptualise better the resources the youths draw on to exercise their reflexive capacity.

\footnotetext{
${ }^{3}$ Research participants were recruited from the following sources: Tottenham Hotspur Foundation, Pushcamp (a local grassroots organisation for youths in Tottenham), 639 Centre (an enterprise hub on Tottenham High Road) and Haringey Council's E18HTEEN (a programme for care leavers).
} 


\section{Discussion of findings}

\section{Preliminaries: reflexivity and the stock of knowledge in youth biographies}

The most striking conclusion to emerge from the data is that Tottenham's young people appear to embody a diverse range of youth identities and reflexive attitudes as they regularly observe themselves in relation to their social environment. This conclusion flies in the face of the way that much of the media in the aftermath of the 2011 riots treated youths from Tottenham as a homogeneous group that lack awareness of their social conditions, as touched upon in the initial sections of this paper. The objective of the remainder of the paper, then, is to focus attention on the significance of recognising young people's experiences and life courses in more nuanced ways. This is achieved by giving empirical flesh to the concept of 'reflexivity' and the more phenomenologically laden term 'stock of knowledge.' Investigating youths in relation to the latter, conceptualised as a stock of lived experiences and dispositions, helps in understanding the life biographies that youths draw on as they reflexively navigate their social environment.

To illustrate, let's look at how the reflexive activity of Temi, a 25-year-old woman from Tottenham with a Yorùbá-Nigerian heritage, is shaped by embedded processes, including the accumulation of past social experiences.

I've always had, like, a deeper look at myself or who I could be. [...] But, can't really say everything's down to me in life. My influences are proper varied.

She proceeds by indicating how previous experiences - through the stock of knowledge influence how she goes about making decisions (with regards to pursuing a career in the arts) in the present.

I remember meeting many creative people back in the day. Yeah, I did this afterschool club thing, where we were encouraged to be creative. That has definitely shaped me. [...] When I do certain things, like being creative, today, it's probably because I had that certain upbringing.

It's hard to say if how I go about my life now - how I make choices - is down to this school, or this experience, or this neighbourhood. 
Temi's ability to think about herself in relation to her social conditions enables her to navigate through life while simultaneously be aware of social influences and her own situation. As has been pointed out in an earlier section, Archer (2013) appears to be correct that this feature of Temi's mental life cannot be explained without reference to reflexivity. Yet, contra Archer, reflexivity, here, is situated socially and constituted historically; that is, reflexivity itself involves previous social experiences since it draws on the stock of knowledge.

\section{Negotiating negative representations}

Research has observed (e.g., Butcher, 2019; cf. Cahill and Cook, in press) that youths are often aware of stereotypes associated with their assumed membership of certain social categories. Young people in Tottenham are no different. Tottenham's youths have been at the receiving end of multiple biased perceptions for years, and, thus, are accustomed to circumnavigate stereotypical representations and their stigmatising implications.

While Temi's reflexion has provided us with examples of how the stock of knowledge informs reflexive orientations, Luke, 23, demonstrates how reflexivity assisted him in not only becoming aware of stigmatising representations, but also diverting him from a path fraught with negative stereotypical associations, many of which are racialised.

I experienced a few things [...] that, like, influenced me. [T]hings in the past, though, don't always control you. I should've been a 'road man' ${ }^{4}$ [laughter]. I mean, with the people around me - the kind of people I grew up with - I should be doing other things, not the things I'm doing now [employed as head sports coach]. Being a 'road man' was kinda expected of me; especially round the time the riots happened. It's easy to just go with the stereotype, the category, [but] categories are not for me, erm, so I chose a different destiny. I didn't wanna be that category even though most thought I'd be just another 'road man.'

This interview excerpt involving Luke highlights multiple themes. It lays bare how others perceive Luke and stereotyping processes that any young person would find hard to stand up to. It also comprises themes that identify subjective variables and more agentic capacities in Luke:

\footnotetext{
4 'Road man' is a term loaded with negative connotations. It refers to a man that typically communicates via slang and hangs out on street corners. According to one of my research participants, Luke, a road man aims to have 'street swagger' - an air of confidence in how he moves about - and knows how to 'play the system on the street.'
} 
how he perceives himself and reflexively deals with negative youth identities. His awareness of the discrepancy between his self-perception and how he is perceived by others is likely to have led to the avoidance of 'self-stereotyping' tendencies and 'predetermined' life course patterns. Luke's resistance to the 'subjectifying force' of stereotypes is reminiscent of the 'rebellious' aspect of Tyler's 'conceptual paradigm of social abjection.' Tyler (2013a: 214) shows how negative representations can both 'get inside' people to regulate subjectivities and lead to 'practices of resistance in which revolting subjects engage to survive stigma and disenfranchisement' (see also Threadgold, 2018: 95-6; in press).

The social categories and stereotypes that Luke called into question are common misrepresentations of youths in Tottenham. Amaia, a sixteen-year-old student with Black Spanish background, who lives and goes to school in Tottenham, believes stereotyping of her peers operates on a large scale.

Since Tottenham riots, the biggest stereotype, I'd say, is that Black [youth], they're all in gangs. $[\ldots]$ You see a Black boy with a hoodie - he's allegedly in a gang.

Amaia draws attention to several intersecting identity attributes from which stigmatising responses are common. Crucially, how stigma operates in relation to these attributes differs: while 'youth' is constructed as a temporary stage experienced at some point by the entire adult population and 'hoodies' are consumable items that go in and out of fashion, the same cannot be said about racialised attributes. Although all three attributes in Amaia's brief example - or at least the intersection of them - can carry the burden of stigma, stigmatising processes concerning racialised features differ in that they may continue long after the racialised person has made the transition into adulthood. Besides, youths wearing hoodies may not, per se, be subject to stigmatising responses; that is, unless those under scrutiny are also subject to racialisation. Stigma, here, operates on multiple levels and is rooted in racism.

Sapphire, a student in her last year of secondary school with a Caribbean heritage, spoke in similar terms to Amaia, and emphasised how stereotypical traits are erroneously attributed to Tottenham's youths.

Some see teenagers in Tottenham as gang members. I feel, like, because I've lived in this area for quite a long time you get to know some of the people and what you realise is the people that are 
put into this stereotype aren't always what people think they are. [...] I feel I'm quite educated on what this is because I know a lot of people who may dress in a certain way and may be seen as a criminal, but they're not involved in anything negative...

In the initial sections of this paper, I outlined how the 'dominant discourse' (mis)represents youths. Sapphire's experiences and reflexive thinking repudiate these representations; “"outsiders" don't know who we are!' she exclaims. When it comes to representing the complexity of youth identities in Tottenham, Amaia suggests that it is Tottenham's youths who inhabit the epistemic privileged position:

I think I understand what's really going on because I'm a teenager and I'm in this, you know, day and age. [laughing] So, I know what it's like to be a teenager, I know what it's like to see what's going on. So, I know that not every boy that wears a hoodie is a gang member.

I have friends who wear hoodies, and they're not gang members, so I know that people's perception of them is wrong, so I'm able to correct them if someone was to come up to me with that opinion.

But, who does Amaia blame for the emergence of these stereotypes (falsely) attributed to her peers?

I personally think that the media influences the way people think and perceive us, especially grown people. [The media] influences people to think wrongly of $[\ldots]$ young people my age sixteen, seventeen; it makes them think that everyone wearing a hoodie must be dangerous, but that's not really the case.

Amaia echoes much of what was said above about how the media whips up moral panics. The media have created an image of Tottenham as if gang membership is a prevalent phenomenon among youths who live there. A recent $\mathrm{BBC}$ programme about a rejuvenated recreation ground in Tottenham exemplifies this. Despite its basic aim of introducing a newly-regenerated park, the programme deemed it necessary to employ negative stereotypical images, referring to Tottenham's recent past as 'a no-go gangland ghetto' (BBC, 2018). Lesedi, who is born and bred in Tottenham with a mother from Kenya, is deeply thoughtful about this concern. Her reflexive activity has prompted awareness of how the media discourse differs from how 'things truly are.' For Lesedi, gang culture is not a noticeable feature of Tottenham. 
Media talks about gangs and Tottenham as if this is a big part of our everyday lives. I've heard about things such as the Tottenham gang, I've never seen them in my life, I don't know anyone [laughter] who's a part of [this] gang...

Despite also being Tottenham-born and raised, Chantal, a secondary school student with a Jamaican background, inhabits different social experiences from Lesedi. Chantal perceives gang membership as not entirely uncommon among her peers. However, her lived experiences of gangs allow for heterogeneity across their members.

[Whether you're a 'white-collar worker' or a 'gang member'] I don't believe what you do defines a person; you could do a boring office job and be the most exciting person in the world, it doesn't define who you are. And, I believe that these [gang members] are being subjected to, like, a stereotype that doesn't even suit them. Just because they find a different way of sorting themselves - of joining a gang - don't mean they aren't good people.

Although the research participants disagree on whether a 'gang culture' is present or not in Tottenham, they all agree that the numerous stereotypical representations presented in the media ${ }^{5}$ are responsible for distorting reality and clouding people's ability to see Tottenham's stereotyped youths as individuated subjects. Amaia elaborates:

...[people] are so used to seeing, like, images of gang members or Black [youths] in the media and stuff. They normally wear hoodies and track suits. So, automatically when you're seeing someone with a hoodie or wearing track suit in Tottenham, you would think, 'Oh, he might be gang related or must have some kind of connections in that gang area.'

\section{The effects of stereotypes on youths}

The media misrepresentations presented by the research participants in the preceding section do not merely influence the ways in which those who have little insight into Tottenham come to perceive Tottenham's youths, they also have a (negative) bearing on those being represented, like

\footnotetext{
${ }^{5}$ The type of media that they refer to here may not be the one that they themselves make use of. While they are more likely to engross themselves in social media than conventional media, such as TV and mainstream newspapers, it is the latter that they believe is the prime disseminator of negative stereotyping.
} 
fifteen-year-old Jaden. Jaden, also from Tottenham, answered as follows to the question, 'How does the media portray Tottenham?': ${ }^{6}$

Negative. We are all represented as gangster and crazy, dangerous bandits. This makes me feel pretty angry and it also makes me think negative things about the area I live in. I wish they showed the positive side more. Then maybe, just maybe I could feel better about where I am from.

'How does this compare to reality?'

It's false; none of my friends are like this. They're kind, smart, creative. [...] People who are not from Tottenham should come and see the reality. (Exposure, 2018)

Despite carrying a reflexive attitude towards his own identity and despite deeming certain media representations to be falsely attributed to his demographic, Jaden still feels it's hard to fully prevent the negative representations from impacting him.

Other research participants drew attention to the fact that stereotypes can gradually enter young people's stocks of knowledge, and, thus, become part of the resources they draw on when making identity claims. As Lesedi states:

...if you see stereotypical images enough times you can be disillusioned and believe that there's actually nothing out there for me except for these stereotypes.

And, if you are regularly perceived in stereotypical terms and positioned in a social context that affords limited opportunities, then, according to Camille, a secondary school student with a Bajan heritage, '[you may] turn to crime or other things that are not viewed as socially acceptable.' However,

if we were to find a way to cater to those people, then maybe we wouldn't have these people feeling like they have to belong to a gang in order to feel accepted in society.

\footnotetext{
${ }^{6}$ The interview with Jaden was part of a workshop delivered by Tottenham Community Press and the youth charity Exposure in September 2018. 
For Camille and the other research participants, then, there appear to be three premises from which we can address stigmatisation and the needs of young people who are regularly portrayed in a negative light:

(1) listen to, and allow for heterogeneity in, youth (Chantal: 'you can't define us from the way that the media portrays us;' Temi: 'I don't get why some think we're all the same in Tottenham coz Tottenham residents are known to be, like, diverse');

(2) acknowledge the role of the media as a potential agent of oppression (Jaden: '[being misrepresented] makes me think negative things;' Chantal: '[youths] are being subjected to, like, a stereotype that doesn't even suit them;' Lesedi: 'young people round here, we are basically not the way TV and newspapers describe us');

(3) contest narratives that perpetuate and normalise negative stereotypes and stigmatising representations of youths.

\section{Further discussion and concluding remarks}

An aim of this paper has been to bring empirical perspectives to bear on the development of a more nuanced appreciation of the lives of youths in an area that has been at the receiving end of negative perceptions and stereotyped responses. This has been achieved through discussions with young individuals from Tottenham and by exploring their reflexive orientations - how they think about themselves in relation to stigmatising youth constructs that primarily emerged in the aftermath of the 2011 riots. This paper's findings show that these images, perpetuated by the media, were unrecognisable to those actually living in Tottenham. Lesedi explains:

I was shocked by how the media talked about youth in Tottenham [after the riots]. People [associate] Tottenham with violent youth culture, although I've never seen it that way.

When the riots happened, I was like, 'what's going on?' But I think some people's perception would be 'Oh, that's kinda obvious it would happen there.'

There was a consensus among the research participants that people perceive Tottenham and its youths through media's 'riot discourse' and it's been hard to escape the harmful effects of the many negative representations. Camille sums up:

So, obviously, Tottenham riots was something that got a lot of media attention, and, it's just, maybe, a label that Tottenham hasn't been able to, like, shake. 
...I'd say [people] negatively perceive Tottenham [and] are just judging by the information they got from the media.

The perpetuation of a series of stereotypical representations of Tottenham's youthful population has enabled judgements about this population to form with cognitive ease. Once formed, stereotypes are applied to all members of Tottenham's youth community. As Tyler (2013b: §3.3) notes about the 'riot discourse:' 'this explosion of hate speech was aimed not only at those who had participated in the rioting and criminal activities such as looting, but at their families and the wider communities in which the rioters lived.' Over time, stereotypical representations can become an integral part of both the 'stereotyper's' and the 'stereotypee's' stocks of knowledge. The latter could lead to 'self-stereotyping,' where the young person sees stereotypes as self-defining. The findings, however, demonstrate little evidence of selfstereotyping processes. Instead, we have seen how youths in Tottenham regularly draw on their reflexive capacity in order to challenge stereotypical depictions of their own demographic profile. But the fact that young 'stereotypees' are (reflexively) aware of stereotypical representations of their social identity does not mean that stereotypes have no negative bearing on the 'stereotypees' (as Jaden pointed out above). Negative stereotypes can infiltrate the stock of knowledge despite being under reflexive scrutiny. Reflexive orientations, thus, should not be studied in isolation. As far as this paper is concerned, to conceptualise youth reflexivity in relation to the stock of knowledge has been an invaluable resource in understanding how youth-identity formation and stereotyping processes are negotiated. Regardless of the intensity of young people's reflexive activity, reflexivity cannot work off a blank canvas, isolating lived experiences, shared meanings and social norms. That is, it cannot operate entirely independent of its 'stock of knowledge.'

At odds with attempts by the 'dominant discourse' to paint a picture of youths in Tottenham as passive, delinquent and a homogeneous group, the findings point to a diverse community of youth subjectivities who seem to 'understand what's really going on,' in the words of Amaia, as they direct their reflexive attitudes towards a range of complex issues. The findings, thus, challenge the assumption that socioeconomically disadvantaged people (of which many of Tottenham's youths would, to various degrees, be considered to be a part) are in any way 'less reflexive' than those in a more privileged position. This proposal, furthermore, calls for a youth 
perspective that allows for qualitative and subjective indicators that can take account of young people's ability to reflect upon themselves in relation to their social environment and the accumulation of multiple lived experiences. By tuning in to the diverse experiences and reflexive voices of youths, we are in a stronger position to document heterogeneity and individual trajectories, as well as understand how youths deal with the oppressive effects of negative representations. 


\section{References}

Adams, M (2006) Hybridizing Habitus and Reflexivity: Towards an Understanding of Contemporary Identity? Sociology, 40(3): 511-28.

Akram, S and Hogan, A (2015) On Reflexivity and the Conduct of the Self in Everyday Life: Reflections on Bourdieu and Archer. The British Journal of Sociology, 66(4): 606-25.

Archer, MS (2012) The Reflexive Imperative in Late Modernity. Cambridge; New York: Cambridge University Press.

Archer, MS (2013) Reflexivity, Sociopedia.isa. Available at: http://www.sagepub.net/isa/admin/viewPDF.aspx?\&art=Reflexivity2013.pdf.

BBC (2018) Countryfile Summer Diaries (Episode 3). London: BBC iPlayer. Available at: https://www.bbc.co.uk/iplayer/episode/b0bhk45z/countryfile-summer-diaries-2018episode-3.

Beck, U ([1986] 1992) Risk Society: Towards a New Modernity. London; Newbury Park, Calif.: Sage Publications.

Bourdieu, P ([1980] 1990) The Logic of Practice. Nice, R (trans.). Cambridge: Polity.

Bourdieu, P ([1979] 2010) Distinction: A Social Critique of the Judgement of Taste. London: Routledge.

Boyce Davies, C (2013) Caribbean Spaces: Escapes from Twilight Zones. Urbana: University of Illinois Press.

Butcher, M (2019) Re-working Encounter: The Role of Reflexivity in Managing Difference. Social \& Cultural Geography, 20(9): 1198-217.

Cahill, $\mathrm{H}$ and Cook, $\mathrm{J}$ (in press) From Life-Course Expectations to Societal Concerns: Seeking Young Adults' Perspectives on Generational Narratives. YOUNG. 
Cameron, D (2011) Riots: David Cameron's Commons Statement in Full. London: bbc.co.uk. Available at: https://www.bbc.co.uk/news/uk-politics-14492789.

Clarke, R (2012) Profiling the 'Rioters': Findings from Manchester. In: Briggs, D (ed.) The English Riots of 2011: A Summer of Discontent. 279-302. Hook: Waterside Press.

Cohen, S ([1972] 2011) Folk Devils and Moral Panics. $3^{\text {rd }}$ ed. London: Routledge.

de St Croix, T (2018) Youth Work, Performativity and the New Youth Impact Agenda: Getting Paid for Numbers? Journal of Education Policy, 33(3): 414-38.

Dillon, D and Fanning, B (2019) Developer-Led Gentrification and Legacies of Urban Policy Failure in Post-Riot Tottenham. Community Development Journal, 54(4): 605-21.

Elster, J (2017) The Temporal Dimension of Reflexivity: Linking Reflexive Orientations to the Stock of Knowledge. Distinktion: Journal of Social Theory, 18(3): 274-93.

End Child Poverty (2018) More Than Half of Children Now Living in Poverty in Some Parts of the UK. Available at: https://www.endchildpoverty.org.uk/more-than-half-of-childrennow-living-in-poverty-in-some-parts-of-the-uk/.

Exposure (2018) Building a Better Tottenham. In Tottenham Community Press, Sept. Available at: http://tottenhamcommunitypress.co.uk/wpcontent/uploads/2018/09/TCP_Sept18_ForWeb_V2-1.pdf.

Farrugia, D (2013) Young People and Structural Inequality: Beyond the Middle Ground. Journal of Youth Studies, 16(5): 679-93.

Farrugia, D (2018) Spaces of Youth: Work, Citizenship and Culture in a Global Context. Abingdon, Oxon: Routledge.

Farrugia, D and Woodman, D (2015) Ultimate Concerns in Late Modernity: Archer, Bourdieu and Reflexivity. The British Journal of Sociology, 66(4): 626-44.

France, A (2007) Understanding Youth in Late Modernity. Maidenhead: Open University Press.

Goffman, E (1963) Stigma: Notes on the Management of Spoiled Identity. Harmondsworth: Penguin. 
Gordon, F (2018) Children, Young People and the Press in a Transitioning Society: Representations, Reactions and Criminalisation. London: Palgrave Macmillan.

Habib, S (2019) Portraits of Place: Critical Pedagogy in the Classroom. In: Habib, S \& Ward, MRM (eds) Identities, Youth and Belonging: International Perspectives. 177-95. Cham, Switzerland: Palgrave Macmillan.

Hall, S, Critcher, C, Jefferson, T, Clarke, J and Roberts, B ([1978] 2013) Policing the Crisis: Mugging, the State, and Law and Order. $2^{\text {nd }}$ ed. Houndmills, Basingstoke, Hampshire: Palgrave Macmillan.

Home Affairs Committee (2011) Policing Large Scale Disorder: Lessons from the Disturbances of August 2011. London. Available at: https://publications.parliament.uk/pa/cm201012/cmselect/cmhaff/1456/1456ii.pdf.

Independent Panel on Tottenham (2012) It Took Another Riot. London: Mayor of London's Office. Available at: https://www.london.gov.uk/file/15966.

Jefferson, T (2015) The 2011 English Riots: A Contextualised, Dynamic, Grounded Exploration. Contention: The Multidisciplinary Journal of Social Protest, 2(2): 5-22.

McKenzie, L (2013) Fox-Trotting the Riot: Slow Rioting in Britain's Inner City, Sociological Research Online, 18(4). Available at: http://www.socresonline.org.uk/18/4/10.html.

Murji, K (2018) Rioting and the Politics of Crisis. Ethnic and Racial Studies, 41(10): 1820-36.

Newburn, T, Cooper, K, Deacon, R and Diski, R (2015) Shopping for Free? Looting, Consumerism and the 2011 Riots. The British Journal of Criminology, 55(5): 987-1004.

Newburn, T, Jones, T and Blaustein, J (2018) Framing the 2011 England Riots: Understanding the Political and Policy Response. The Howard Journal of Crime and Justice, 57(3): 33962.

Nico, M and Caetano, A (2017) Untying Conceptual Knots: The Analytical Limits of the Concepts of De-Standardisation and Reflexivity. Sociology, 51(3): 666-84.

Nomis (2019) 2011 Census. University of Durham/Office for National Statistics. Available at: https://www.nomisweb.co.uk/.

Schütz, A ([1945] 1962) Collected Papers. Natanson, M (ed.). The Hague: M. Nijhoff.

Dr Julius Elster, London Metropolitan University

j.elster@londonmet.ac.uk 
Stott, C, Drury, J and Reicher, S (2017) On the Role of a Social Identity Analysis in Articulating Structure and Collective Action: The 2011 Riots in Tottenham and Hackney. The British Journal of Criminology, 57(4): 964-81.

Sweetman, P (2003) Twenty-First Century Dis-ease? Habitual Reflexivity or the Reflexive Habitus. The Sociological Review, 51(4): 528-49.

Threadgold, S (2018) Youth, Class and Everyday Struggles. London; New York: Routledge, Taylor \& Francis Group.

Threadgold, S (in press) Figures of Youth: On the Very Object of Youth Studies. Journal of Youth Studies.

Tyler, I (2013a) Revolting Subjects: Social Abjection and Resistance in Neoliberal Britain. London: Zed Books Ltd.

Tyler, I (2013b) The Riots of the Underclass?: Stigmatisation, Mediation and the Government of Poverty and Disadvantage in Neoliberal Britain, Sociological Research Online, 18(4). Available at: http://www.socresonline.org.uk/18/4/6.html.

Tyler, I (2018) Resituating Erving Goffman: From Stigma Power to Black Power. The Sociological Review, 66(4): 744-65.

Vertovec, S (2007) Super-Diversity and Its Implications. Ethnic and Racial Studies, 30(6): 102454.

Visser, K (in press) 'Because We're All Different' - Everyday Experiences of Belonging among Young People from Immigrant Backgrounds in Tottenham. Geoforum.

Wessendorf, S (2014) Commonplace Diversity: Social Relations in a Super-Diverse Context. Basingstoke: Palgrave Macmillan.

Woodman, D (2009) The Mysterious Case of the Pervasive Choice Biography: Ulrich Beck, Structure/Agency, and the Middling State of Theory in the Sociology of Youth. Journal of Youth Studies, 12(3): 243-56.

Wyn, J and Woodman, D (2007) Generation, Youth and Social Change in Australia. Journal of Youth Studies, 9(5): 495-514. 